\title{
İçme Sütü Tüketiminde Marka Seçiciliğinde Etkili Faktörlerin Analizi: İzmir İli Örneği
}

\author{
Elif Merve KAHRAMAN ${ }^{1} *$ Harun Raşit UYSAL ${ }^{2}$
}

\section{$\ddot{O} z$}

$\mathrm{Bu}$ araştırmada, önemli bir besin kaynağı olan sütün tüketiminde markanın önemi incelenmiştir. $\mathrm{Bu}$ bağlamda İzmir ilinin değişik ilçelerinde yaşayan farklı demografik özelliklere sahip 407 kişiye anket uygulanmıştır. Anket verileri betimleyici istatistik ve Ki-kare testi kullanılarak analiz edilmiş olup, tüketicilerin \%70.5'inin marka tercihlerinin olduğu tespit edilmiştir. Bu tercihte; "güvenilirlik (sağlıkkalite)," "tat ve lezzet" ile "tüketiciye verilen önem" unsurlarının sıklıkla dikkate alındığı saptanmıştır. Ayrıca, markanın; ürünün kalitesi, garanti olgusu ve firmanın saygınlığı olarak algılandığı, kalitenin düşmesi ve firmanın ayıplı ürün üretenler arasında sayılması içme sütünde marka değiştirmede en etkili nedenler olarak belirlenmiştir. Tüketicilerin büyük çoğunluğu tercih ettikleri markadan beklentilerini yeterli bulmuşlardır.

Anahtar Kelimeler: Süt, Marka tercihi, Marka değiştirme.

\section{Examining the Important Factors Influencing Brand Preference of Drinking Milk: A Case of İzmir}

\begin{abstract}
This study aimed to examine the importance of brand preference in consuming milk being a basic nutritional source. A survey was conducted with 407 individuals living in different counties of Izmir and having varied demographic characteristics. The collected data were analysed with descriptive statistics and Chi-square tests. It was found that $70.5 \%$ of participants prefer buying a certain brand. Their brand preference was mainly influenced by "trustworthiness (health-quality)", "taste and flavour" and "devoting importance to costumers". While they perceived brand as "quality", "terms of guarantee" and "reputation of a company", they tended to change their brand preference because of "reduced quality" and "companies producing defective products". Most of the participants also indicated that the brand they choose meets their expectations.
\end{abstract}

Keywords: Milk, Brand preference, Changing Brand.

ORCID ID (Yazar sirasına göre)

0000-0002-6742-1817, 0000-0002-4032-6545

\footnotetext{
Yayın Kuruluna Geliş Tarihi: 13.04.2020

Kabul Tarihi: 26.06.2020

${ }^{1}$ İstanbul Aydın Üniversitesi, Uygulamalı Bilimler YO, Gıda Teknolojisi, İstanbul, Türkiye

${ }^{2}$ Ege Üniversitesi, Ziraat Fakültesi, Süt Teknolojisi Bölümü, İzmir, Türkiye

*E-posta: emervekahraman@aydin.edu.tr

*Bu çalışma birinci yazarın doktora tezinden üretilmiştir.
} 


\section{İçme Sütü Tüketiminde Marka Seçiciliğinde Etkili Faktörlerin Analizi: İzmir İli Örneği}

\section{Giriş}

Özellikle 1980'li yıllardan itibaren hayatın hemen her alanında başlayan değișim ve dönüşüm; günümüzde üretim teknolojilerini de içine alan "Endüstri 4.0" kavramı ile birlikte çok daha hızlı bir biçimde şekillenmektedir. Gida üreticilerinin de bu entegrasyonda ilk sıralarda olması beklenmektedir (Ötleş ve Özyurt, 2016). Tüm bu gelişmelerden ve buna dayalı küresel rekabet şartlarından en çok etkilenenlerin ilk siralarında tüketiciler gelmektedir. $O$ halde piyasa aktörlerinin tüketici tercihlerini önemseyen ve dikkate alan politikaları geliştirme zorunlulukları vardır. Hedef kitle tüketicinin ve en büyük tüketici olan insanın temel ihtiyaçlarının en birincil sirasinda beslenme yer almaktadır. Besin maddelerinin geleneksel üretim ve tüketim alışkanlıkları günümüz şartlarında içeriğinde pek çok sorunsal alanı da barındıracak şekilde değişmiştir. Tüm bu gelişmeler tüketicinin "marka" kavramına yaklaşımını etkilemiş, besin maddeleri dahil tüketime sunulan pek çok ürün ya da ürün ile yapılan eylem tüketici tarafından marka adıyla anılır olmuştur (Karadavut, 2016).

Adeta tüketime sunulan ürünün kimlik ya da garanti belgesi olarak algılan "marka" kavramı; tüm tüketim ürünlerinde olduğu gibi küresel ölçekte gida maddelerinde de etkisini göstermeye başlamıştır. Yeterli olmamasına rağmen yapılan araştırmalar; tüketim tercihleri geniş ölçüde değişime uğrayan tüketicilerin gıda maddelerini, dolayısıyla içme sütü ve süt ürünlerini alırken de markayı önemsediğini ve markalı ürünlere yoğunlaştığını göstermektedir (Erdem, 2004; Uzungöz ve Gülşen, 2007; Çetinkaya, 2010; Gündüz ve ark., 2013).

Yeni doğmuş bir bebek yalnızca anne sütüyle beslenebilir. Demek ki süt, bir yavrunun ihtiyacı olan tüm besin maddelerini yeterli ve dengeli bir şekilde içermektedir. Dünyada böyle bir gida maddesi yoktur, bu nedenle süt dünyanın en mükemmel gida maddesi olarak bilinmektedir (Uysal, 2012). Ancak ülkemizde yapılan araştırmalara ve yeterli olmasa da mevcut istatistiksel verilere göre süt ve süt ürünlerinin tüketimi, dolayısıyla içme sütü tüketim miktarı dünya ve $\mathrm{AB}$ ülkelerinin çok gerisindedir (Erdal ve Tokgöz, 2011; Onurlubaş ve Çakırlar, 2016). Ayrıca, içme sütü ve genel olarak süt ürünlerinin tüketimini istenilen seviye çıkarmak için çeşitli çalışmalar yapılıyor olsa da uygulama sonuçları analiz edildiğinde bu çalışmaların süt tüketimini artırmada yetersiz kaldığı ifade edilebilir. Örneğin, Ulusal Süt Konseyi'nin 2014 yılında yayınladığı rapora göre 2013 yılında ülkemizde kişi başı içme sütü tüketimi 37.3 kilogram ve 2019 yılında yayınladığı başka rapora göre 2018 yılında ülkemizde kişi başı içme sütü tüketimi 41.5 kilogram olarak tahmin edilmiştir (Ulusal Süt Konseyi, 2014; 2019).

Genelde gida ürünlerinin özelde ise paketli içme sütlerinin alımında markanın etkili olduğunu tespit eden çalışmaların sonuçlarından yola çıkarak (Topçu, 2006; Dilber ve Dilber, 2013), bu çalışmanın amacı; süt tüketiminde marka seçiciliğini etkileyen faktörleri ve bunların önem derecesini belirlemektir. $\mathrm{Bu}$ amaç bağlamında, araştırmanın problemleri aşağıda listelenmiştir.

- Tüketicilerin marka tercihinde etkili olan demografik özellikler nelerdir?

- Tüketicilerin içme sütünde marka tercihini etkileyen faktörler nelerdir?

- Tüketicilerin içme sütünde marka tercihinin değiştirmede etkili olan faktörler nelerdir?

\section{Literatür Özeti}

İçme sütü tüketiminde marka seçiciliğinde etkili faktörlerin analizinden önce genel olarak süt ve sütün özellikleri, sütün beslenme açısından önemi ve süt tüketimi, tüketici tercihlerini belirleyen unsurlar ile marka kavramı üzerinde kısa bilgiler verilecektir.

\section{Genel Olarak Süt}

Yapılan tanımları günümüz gelişmeleri ile birlikte değerlendirdiğimizde sütü; "Memeli canlıların öncelikle yavrularını besleyebilmek için, süt bezlerinde oluşan ve canlı türleri itibariyle farklı özellik, tat, renk, koku ve kıvamda olsa da; genel olarak temel besin maddelerini yeteri kadar içinde barındıran, hiçbir işleme tutulmadan yavru tarafından tüketilebilen; pek çok işleme tabi tutularak 


\section{İçme Sütü Tüketiminde Marka Seçiciliğinde Etkili Faktörlerin Analizi: İzmir İli Örneği}

tüketilmesi bir bakıma zorunlu temel besin maddelerinin hammaddesi olan, meme bezi salgısı" olarak tanımlamak mümkündür (Kahraman, 2016).

İnsanlık tarihi kadar geçmişi olan süt; bir yaşam mucizesi denilebilecek kadar büyük besin değerine sahiptir. Mevcut kayıtlara göre süt, M.Ö. 8000-6000 y1llarında Orta Asya'da tanınmış ve sığırlar evcilleştirilmeye başlanmıştır. İngiliz arkeolog Mellart, Çatal Höyük'te yaptığı çalışmalarda tereyağı, peynir ve ayranın neolitik devire (M.Ö. 8000-5000) ait olabileceğini bildirmiştir (Ambalajlı Süt ve Süt Ürünleri Sanayicileri Derneği, 2019).

Süt, elde edildiği canlıya göre; inek sütü, koyun sütü, keçi sütü, manda sütü gibi adlandırılır. Süt aynı zamanda bileşimindeki maddelerin fizikokimyasal özellikleri nedeniyle, diğer gida maddelerinin üretiminde ve bazı sanayi dallarında büyük öneme sahiptir ve bu nedenle süt, polidispers bir gıdadır (Metin, 2012). Süt sadece çocukların değil her yaştan insan tarafindan tüketilmesi gereken önemli bir besin maddesidir. Süt șekeri (laktoz) doğada yalnızca süt ve süt ürünlerinde bulunur. Şeker olmasına rağmen önemli bir karbonhidrat kaynağı olmayan laktoz, özellikle zayıflama diyetinde, ayrıca beyin ve sinir dokularının oluşumunda önemli rol oynamaktadır (Metin, 2012; Uysal, 2012). Mevcut bilgilere göre memeden sağılan sütte 200 civarında madde bulunmaktadır (Metin, 2012). Sütün büyük bir bölümü su olmakla beraber, kalan kısmı yaklaşık \%4 laktoz, \%4 yağ, \%3.3 protein, \%0.19 protein olmayan azotlu madde ve $\% 0.07$ kül içermektedir (Niamsiri ve Batt, 2009). Terin ve ark. (2015); son y1llarda yapılan klinik ve biyokimyasal araştırmaları referans göstererek (Gurr, 1992; Massey, 2001; Bus ve Worsley, 2003) süt tüketiminin özellikle de az yağlı sütlerin hipertansiyon, diș hastalıkları, kolon kanseri ve kalp hastalıklarının azalmasında önemli olduğunu bildirmektedir.

Süt üretimi açısından dünya sıralamasında ön siralarda yer alan ülkemizde; istatistiksel verilerin yetersizliğine rağmen bilim insanlarınca sahada yapılan pek çok araştırma sonuçlarına göre maalesef ki süt tüketiminin yeterli seviyede olduğunu söylemek mümkün değildir (Onurlubaş ve Çakırlar, 2016). Daha önce Türkiye'de yapılan araştırma sonuçlarına bakıldığında da tüketicilerin süt tüketim alışkanlığının olduğu, ancak tüketim miktarının diğer ülkelerin gerisinde kaldığı, dolayısıyla en iyimser rakamlara göre ülke genelinde kişi baş1 içme sütü tüketim miktarının 2018 yılında 41.5 kilogram olduğu tahmin edilmiştir (Ulusal Süt Konseyi, 2019). TÜİK tarafindan yayımlanan son verilerin analizinde; toplam hayvan sayısındaki artışa paralel olarak sağılan hayvan sayısında, dolayısıyla süt üretimindeki artış eğilimin devam ettiği görülmektedir. Çizelge l'de yer alan veriler incelendiğinde; 2018 yılında toplam hayvan sayıs $\% 4.83$ oranında artarken, sağılan hayvan sayıs1 \%7.21; üretilen süt miktarı ise $\% 6.86$ oranında yükselmiştir.

Çizelge 1. Hayvan sayısı ve süt üretim miktarı 2017-2018 yılları (TÜİK, 2019)

\begin{tabular}{|c|c|c|c|c|}
\hline \multirow{2}{*}{ Tür } & Y1l & $\begin{array}{c}\text { Toplam } \\
\text { hayvan } \\
\text { say1s1 (Bin } \\
\text { baş) }\end{array}$ & $\begin{array}{c}\text { Sağılan } \\
\text { hayvan } \\
\text { say1s1 } \\
\text { (Bin baş) }\end{array}$ & $\begin{array}{c}\text { Süt } \\
\text { üretim } \\
\text { miktar1 } \\
\text { (Bin ton) }\end{array}$ \\
\hline \multirow{2}{*}{ Koyun } & 2017 & 33678 & 17503 & 1345 \\
\cline { 2 - 5 } & 2018 & 35195 & 18819 & 1446 \\
\hline \multirow{2}{*}{ Keçi } & 2017 & 10635 & 4964 & 523 \\
\cline { 2 - 5 } Siğır & 2018 & 10922 & 5327 & 562 \\
\cline { 2 - 5 } & 2017 & 15944 & 5969 & 18762 \\
\hline \multirow{2}{*}{ Manda } & 2018 & 17042 & 6338 & 20037 \\
\cline { 2 - 5 } & 2018 & 161 & 69 & 69 \\
\hline \multirow{2}{*}{ Toplam } & 2017 & 60418 & 28505 & 20699 \\
\cline { 2 - 5 } & 2018 & 63337 & 30560 & 22121 \\
\hline
\end{tabular}

\section{Genel Olarak Marka}

Marka, bir teşebbüsün mal veya hizmetlerini bir başka teșebbüsün mal veya hizmetlerinden ayırt etmeyi sağlaması koşuluyla, kişi adları dahil, özellikle sözcükler, şekiller, harfler, sayılar, malların biçimi veya ambalajları gibi çizimle görüntülenebilen veya benzer biçimde ifade edilebilen, bask1 yoluyla yayınlanabilen ve çoğaltılabilen her türlü işaretleri içerir (556 Sayılı Kanun Hükmünde Kararname Md. $5^{3}$ ).

\footnotetext{
3 27.06.1995 tarih ve 22326 sayılı Resmî Gazete'de yayımlanarak yürürlüğe girmiştir.
} 


\section{İçme Sütü Tüketiminde Marka Seçiciliğinde Etkili Faktörlerin Analizi: İzmir İli Örneği}

Kotler (2000)'e göre marka; üretici ve satıcının, tüketicilere belirli özellik, fayda ve hizmeti sürekli olarak sunacağının bir vaadidir. Marka; aynı zamanda kalite garantisini de ifade eder ve ürüne yönelik olarak tüketiciler için nitelik, fayda, değer ve kişilik gibi farklı anlamlar taşır (Gavcar ve Didin, 2007).

Bugün itibariyle özellikle genç tüketiciler bakımından vazgeçilmezler arasında yer alan "marka" konusunda bağl1lığ yaratmak için bu tüketicilere doğru mesajın iletilmesi ve marka fonksiyonlarının bu kitle tarafından doğru algılanması çok önemlidir (Marangoz, 2006). Ayrıca marka bağlılığı yüksek düzeyde olan tüketicilerin pazarlama ve satıs gayretlerinden çok daha az etkilendiği ve daha sık ürün aldığı ileri sürülmektedir (Neal, 1999). Marka tüketiciler bakımından, bir ürünü tanımanın en kolay yolu olup, üründen memnun oldukları ve ihtiyaçlarını karşıladığı sürece, üründen kaçınmamalarına yardımcı olur. Ürünün kaynağını gösteren marka, aynı zamanda ürünün kalite güvencesi ve garantisini taşır. Marka, tüketicinin ürün ve hizmete ilişkin fikrini/kanaatini yansıtırken, firmalar/üreticiler arasındaki rekabette ön plana çıkan unsur olmaktadır. Firmalar ürettikleri ürün ve hizmetlerinin sürekli talep edilmesini ve buna bağlı olarak yüksek ve aynı zamanda düzenli ve sürekli satış hasılatı ve nakit akışının devamına sahip olmak istemektedirler. Böylece marka, değer ve güç göstergesi konumuna gelmektedir (Marangoz, 2006).

Süt ve süt ürünleri başta olmak üzere genel gıda sektöründe marka ve markalaşma her geçen gün daha da önem kazanmakta ve hukuki güvence kapsamında korunmaktadır. Örneğin, Alman Karlsruhe Eyalet Yüksek Mahkemesinin 23 Ocak 2013 tarihli kararında; "Erzincan Peyniri" ve "Erzincan Kaşarı" adlı iki ürünün Hollanda sütünden üretildiği için coğrafi köken bakımından yanıltıcı olduğu gerekçesiyle piyasaya sürülmesini menetmiştir (Yarayan, 2015). Bu örnekten de anlaşılacağı üzere marka sadece üreticilerin haklarını koruyan bir unsur değil, tüketicilerin herhangi bir nedenle yanılmalarına mani olma katkısı da sunmaktadır.
Tüketici Davranışlarını Etkileyen Faktörler

Tüketici davranışlarını etkileyen faktörler genel olarak kültürel, sosyal, psikolojik ve kişisel faktörler olarak sınıflandırılmaktadır. Kültürel özellikler, alt kültür ve sosyal sınıf satın alma davranışında önemli faktörlerdir. Diğer taraftan tüketicilerin davranışı danışma grupları, aile, rol ve statü gibi sosyal faktörler tarafından da etkilenir. Kişisel faktörler; tüketicinin yaş1, yaşam dönemi, cinsiyeti, mesleği, ekonomik gücü, yaşam tarzı ve kişiliği gibi özellikleri kapsamaktadır. Pazarlamacıların denetim altına alamadığ1 en önemli çevre elemanı tüketici olup, yapılan çeşitli araştırmalarda marka sadakati ile tüketici özellikleri arasında çeşitli ilişkilerin bulunduğu tespit edilmiștir (Çakır ve ark., 2010; Durmaz ve ark., 2011; Keskin ve Baş, 2016; Onurlubaş ve Çakırlar, 2016). Tüketici davranışlarını etkileyen psikolojik faktörler Kotler (2003)'e göre; motivasyon, algılama, öğrenme ve inanç ve tutumlardır (Çakır ve ark., 2010). Tüketici davranışlarını etkileyen bu temel faktörlerin bir kısmına ilişkin şu örnekler verilebilir. Son yıllarda dünyadaki modernleşme hareketleriyle birlikte eğitimli kadın sayısında meydana gelen artışın bir sonucu olarak kadınlar iş hayatında daha fazla yer almaya başlamıştır. Kadınların gelir elde eden konuma yükselmeleriyle toplumdaki rolleri değişmiş ve ailenin satın alma kararlarında söz sahibi olmaya başlamışlardır (Lee ve Beatty, 2002; Onurlubaş ve Çakırlar, 2016'dan). İnsanlar için duygular önemlidir ve yoğun hissedilen duygular uzun süre hafizada kalabilir. Duygular insan davranışlarını şekillendirir ve kişileri motive ederek harekete geçirir, bu yüzden pazarlamacılar duygularla yakından ilgilenmektedir (Sashikala, 2007; Onurlubaş ve Çakırlar, 2016'dan).

Günümüz toplumlarda belli bazı yaşam tarzlarının, belli grupların ayrıcalığında olduğuna ilişkin yaygın düşünce aşılmış bulunmaktadır. $\mathrm{Bu}$ türden toplumlar, pazar araştırmacılarının terminolojisi ile "sabit statü grupları" veya "toplumsal siniflar" gibi yeni tüketim modellerinin belirleyicisi olabilecek kavramların tamamen ortadan kaybolduğu toplumlardır. Bu durum "post-modern" olarak tanımlanır (Bocock, 1997; Çınar ve Çubukçu, 


\section{İçme Sütü Tüketiminde Marka Seçiciliğinde Etkili Faktörlerin Analizi: İzmir İli Örneği}

2009'dan).
modernizmin $\begin{gathered}\text { Postmodernizm } \\ \text { oluşturduğu }\end{gathered} \begin{array}{r}\text { kavram1, } \\ \text { problemleri/ }\end{array}$ sıkıntıları aşmayı hedefleyen inatçı ve oldukça kaotik bir akım olarak da tanımlanmaktadır (Harvey, 2006, Azizağaoğlu ve Altunışık, 2012'den). Postmodern dünyada tüketicilerin seçimleri değişkenlik gösterdiğinden kitlesel olmayan üretim/tüketim biçimlerine doğru yönelmeler olmaktadır (Azizağaoğlu ve Altunışık, 2012).

\section{Materyal ve Yöntem \\ Örneklem}

Örneklem, rastgele örneklem yöntemi ile belirlenmiştir. $\mathrm{Bu}$ kapsamda, İzmir il merkezinde ve merkez dıșında kalan ilçelerde yaşayan kişilere erişmek amacıyla çalışmada kullanılan anket basılı ve elektronik ortamda hazırlanmış, TÜIKK verilerinden hareketle İzmir'de nüfus yoğunluğuna orantılı olarak, ayrıca seçilen kişilerin temsil ediciliğini artırmak amacı ile on iki ilçenin işlek caddelerinde farklı zaman dilimlerinde (08.00$10.00 ; 12: 30-14: 30 ; 16: 30-20: 00)$ sabah, öğlen ve akşam olmak üzere kişilerle yüz yüze görüşme yapılmıştır. Saat dilimlerine ayırma nedeni farklı saat dilimlerinde nitelikleri değişik kişilerin sokağa çıkacağı varsayımdır (Kalton, 2009; Roy ve Acharya, 2016).

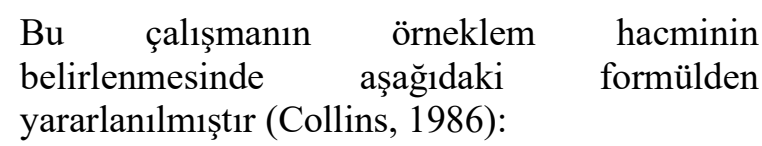

$\mathrm{n}=\mathrm{t}^{2} \cdot[1+(0.02)(\mathrm{b}-1)] \cdot(\mathrm{p} \cdot \mathrm{q}) / \mathrm{e}^{2}$

$\mathrm{n}$ : Örneklem hacmi, t: \%95 önem derecesine karşıllk gelen tablo değeri (1.96), b: Örnekleme aşaması (bu çalışmada tek aşamalı olduğu için 1 olarak alınmıştır), p: İncelenen olayın ana kütlede gerçekleşme olasılığı, $q=(1-p)$ : İncelenen olayın gerçekleşmeme olasılığ Kabul edilen hata payıdır (bu çalışmada hata payı $\% 5$ olarak ön görülmüştür).

Denklemde $b=1$ alındığında, eşitlik aşağıdaki şekle dönüşmüştür:

$n=t^{2} \cdot(p \cdot q) / e^{2}$
$\mathrm{Bu}$ formüle göre örneklem hacmi;

$\mathrm{n}=1.96^{2} \times(0.50 \times 0.50) / 0.05^{2} \rightarrow \mathrm{n}=384$

Örneklem hacmi 384 olarak hesaplanmış ve ankette kayıp değerler olacağı dikkate alınarak tanitılan anket gönüllü olan 500 kişiye uygulanmış ya da ulaştırılmış̧ır. Kat1lımcilardan 93'ünün anketinde eksik veriler olduğu tespit edilmiş olup, bu anketler bütünüyle değerlendirme dış1 tutulmuştur. 407 katılımcının anketi ise değerlendirmeye alınmıştır.

\section{Veri Toplama Aracı}

İzmir ili ölçeğinde gerçekleştirilen araştırmada, içme sütü tüketen katılımcıların her birine, marka tercihleri yanında bu tercihlerini etkileyen faktörlerin tespit edilebilmesi için beş ana bölümden oluşan anket uygulanmıştır.

Anketin ilk bölümünde; kat1lımcıların cinsiyet, yaş, medeni durum, öğrenim durumu, çalışma durumu ve hane gelirinden oluşan demografik özellikleri dikkate alınmıştır. İkinci bölümde ise katılımcıların içme sütü tüketip tüketmedikleri ve içme sütü alımında bir marka tercihlerinin olup-olmadığı sorgulanmıştır. Üçüncü bolümde marka ile ilgili genel sorular yer almaktadır. Dördüncü ve beşinci bölümde ise marka tercihinde ve marka değiştirmede kendilerini etkileyen faktörleri önem derecelerine göre belirtmeleri istenmiştir.

Dördüncü ve beşinci bölümde yer alan sorulara uygulanan güvenilirlik testinde, cronbach alpha değeri 0.907 bulunmuştur. Hesaplanan bu değer, anketin tüketici tercihlerini belirleme düzeyini mükemmel olarak ifade ettiğini göstermektedir.

\section{Verilerin Toplanması ve Analizi}

İçme sütü tüketiminde marka seçiciliğinde etkili faktörlerin belirlenmesini amaçlayan bu çalışmanın verileri, 5 Haziran 2016 ve 8 Temmuz 2016 tarihleri arasinda anketler aracılığıyla toplanmıştır. $\mathrm{Bu}$ yöntemle veri derlemek başka yöntemlere kıyasla düşük maliyetli olup, ayrıca uygun bir biçimde toplandığında elde edilen sonuçların 


\section{İçme Sütü Tüketiminde Marka Seçiciliğinde Etkili Faktörlerin Analizi: İzmir İli Örneği}

evrene/bütüne genellemesi mümkündür (Valentino, 1999; Abu ve ark., 2011). Aldridge ve Levine (2001) göre; anket yönteminde araştırmacının, katılımcıların cevaplarını etkileme potansiyeli azdır, ayrıca bu yöntemde katılımcıların kimlikleri gizli tutulabilir, diğer taraftan anket yönteminde açık ve kapalı uçlu sorular aynı veri toplama aracında yer alabilir. $\mathrm{Bu}$ avantajlarının yanında anket yönteminin doğası gereği bazı sınırlılıklar da mevcuttur. Örneğin, anket uygulama sirasında yeniden düzenlenemeyeceği için, bazı sorular katılımcılar tarafindan anlaşılmadığında anketin kullanılabilirliğini azaltır (Sekaran, 2002; Babbie ve Mouton, 2009). Bu sinırlılığın çalışmaya etkisi, genellikle pilot çalışma veya anketin asıl uygulamadan önce uzmanlara inceletilmesi ile azaltılmaya çalışılmıştır. İzmir ili ölçeğinde gerçekleştirilen bu araştırmada; anket soru formu, belirtilen bu avantaj ve dezavantajlar göz önünde bulundurularak düzenlenmiştir.

$\mathrm{Bu}$ çalışmada elde edilen verilerin analizinde betimleyici istatistik ve Ki-kare testi kullanılmıştır.

\section{Bulgular}

Tüketicilerin Marka Tercihinin Demografik Özellikleri Acısından İncelenmesi

Araştırmadan elde edilen genel veriler Çizelge 2'de yer almaktadır. Buna göre; anket kapsamındaki 407 katılımcıdan, 305'inin içme sütü tükettikleri, içme sütü tüketen bu katılımcıların da \%70.5'i olan 215'inin içme sütünde marka tercihlerinin bulunduğu, $\% 29.5$ 'inin ise marka tercihlerinin olmadığ 1 tespit edilmiştir.

Çizelge 2 verilerinin analizinde; içme sütü tüketen kadınların \%74.9'unun; erkeklerin ise \%65.2'sinin marka tercihinin olduğundan dolayı, kadınların daha çok marka tercihinde bulundukları anlaşılmaktadır. Fakat yapılan kikare analizi sonucuna göre, cinsiyet durumu ile marka tercihi arasında istatistiksel olarak anlamlı bir ilişkinin bulunmadığı tespit edilmiştir $\left(\chi^{2}=3.371\right.$, s.d. $\left.=1, p>0.05\right)$.
Ancak Çizelge 2'de yer alan verilerden de açık bir şekilde görüleceği üzere; gençlerden oluşan 18-35 yaş grubunun, orta ve üstü yaş grubuna kıyasla daha çok marka tercihlerinin bulunduğu anlaşılmaktadır. Bulgulara uygulanan ki-kare testlerinde yaş faktörü ile marka tercihi arasında istatistiksel olarak anlamlı bir ilişki olduğu sonucuna varılmıştır $\left(\chi^{2}=15.471, \quad\right.$ s.d. $=4$, $p<0.05$, Cramer's $V=0.225)$.

Çizelge 2. İçme sütü tüketimi ve marka tercihi

\begin{tabular}{|c|c|c|c|}
\hline \multirow{2}{*}{$\begin{array}{l}\text { Demografik } \\
\text { Özellik }\end{array}$} & \multicolumn{3}{|c|}{ Marka Tercihi } \\
\hline & Evet & Hayır & Ki-kare sonuçları \\
\hline Genel & 215 & 90 & \\
\hline \multicolumn{4}{|c|}{ Cinsiyet } \\
\hline Kadın & 125 & 42 & \multirow{2}{*}{$\begin{array}{c}\chi^{2}=3.371, \text { s.d. }=1 \\
p=0.066\end{array}$} \\
\hline Erkek & 90 & 48 & \\
\hline \multicolumn{4}{|c|}{ Yaş } \\
\hline $18-25$ & 79 & 40 & \multirow{5}{*}{$\begin{array}{c}\chi^{2}=15.471, \text { s.d. }=4, \\
p=0.004^{*} \\
\text { Cramer's V=0.249 }\end{array}$} \\
\hline $26-35$ & 91 & 24 & \\
\hline $36-45$ & 33 & 11 & \\
\hline $46-55$ & 10 & 10 & \\
\hline $56+$ & 2 & 5 & \\
\hline \multicolumn{4}{|c|}{ Medeni Durum } \\
\hline Bekar & 128 & 53 & \multirow{3}{*}{$\begin{array}{c}\chi^{2}=0.089, \text { s.d. }=2 \\
p=0.956\end{array}$} \\
\hline Evli & 79 & 33 & \\
\hline Dul & 8 & 4 & \\
\hline \multicolumn{4}{|c|}{ Öğrenim Durumu } \\
\hline İlk+orta & 14 & 5 & \multirow{4}{*}{$\begin{array}{c}\chi^{2}=2.378, \text { s.d. }=4 \\
p=0.795\end{array}$} \\
\hline Lise & 63 & 33 & \\
\hline Ön Lisans & 27 & 10 & \\
\hline Lisans+ & 91 & 35 & \\
\hline \multicolumn{4}{|c|}{ Çalışma Durumu } \\
\hline Calismiyor & 90 & 41 & \multirow{2}{*}{$\begin{array}{c}\chi^{2}=0.354, \text { s.d. }=1 \\
p=0.552\end{array}$} \\
\hline Çalışan & 125 & 49 & \\
\hline \multicolumn{4}{|c|}{ Hane Aylık Geliri } \\
\hline$<1.300 .-$ & 14 & 9 & \multirow{5}{*}{$\begin{array}{c}\chi^{2}=5.146, \text { s.d. }=4 \\
p=0.273\end{array}$} \\
\hline $1301-2000$ & 45 & 25 & \\
\hline $2001-3000$ & 48 & 23 & \\
\hline $3001-4000$ & 44 & 13 & \\
\hline$>4001+$ & 64 & 20 & \\
\hline
\end{tabular}

Aynı çizelgede yer alan verilere göre bekar katılımciların (\%70.7) evlilere (\%70.5) nazaran çok az bir farkla da olsa marka tercihi eğilimlerinin yüksek olduğu, ancak uygulanan ki-kare testinden elde edilen sonuç; medeni durum ile marka tercihi arasinda anlamlı bir ilişkinin bulunmadığını ortaya koymuştur $\left(\chi^{2}=0.089\right.$, s.d. $\left.=2, p>0.05\right)$. 


\section{İçme Sütü Tüketiminde Marka Seçiciliğinde Etkili Faktörlerin Analizi: İzmir İli Örneği}

İçme sütü tüketiminde marka tercihlerine ilişkin veriler tetkik edildiğinde, süt tükettiğini bildiren toplam 305 katılımcı içinde lise mezunu olanların \%65.6'ü süt tüketimde marka seçerken, ilk ve ortaokul mezunlarında bu oran $\% 73.7$ olarak tespit edilmiştir. $\mathrm{Bu}$ verilere uygulanan ki-kare testi marka tercihi ile öğrenim durumu arasında anlamlı bir ilişkinin olmadığını ortaya koymuştur $\left(\chi^{2}=2.378\right.$, s.d. $=5$, $p>0.05)$.

Çalışma durumuna göre verilerin değerlendirilmesinde çalışan ve çalışmayanların neredeyse eşit oranda marka tercih ettikleri anlaşılmıştır. Dolayısıyla çalışma durumu özelliği de marka tercihinde istatistiksel olarak anlamlı bir ilişkiye sahip değildir $\left(\chi^{2}=0.354\right.$, s.d. $=1, p>0.05$ ).

Nihayetinde marka tercihi ilişkin derlenen verilerin analizinde gelir seviyesi yükseldikçe marka tercihinde artış görülmüştür. Verilere uygulanan ki-kare testi sonuçları, hane aylık gelir seviyesi ile marka tercihinde arasinda anlamlı bir ilişkinin bulunmadığını ortaya koymuştur $\left(\chi^{2}=5.146\right.$, s.d. $\left.=4, p>0.05\right)$.

Tüketicilerin marka ile ilgili genel sorulara verdikleri cevaplar ile içme sütünde marka tercihini etkileyen faktörlerin incelenmesi

Araştırma kapsamında katılımcılara yöneltilen marka ile ilgili genel sorular, markanın onlara ne ifade ettiği, tercih ettikleri markayı başkalarına önerip önermeyeceklerini ve içme sütü alımındaki ambalaj tercihlerini içermektedir. Katılımcıların \%51.5'ine göre marka ürünün kalitesini, \%30.8'ine göre marka ürünün garantili olmasın1, \%10.2'sine göre üretici firmanın saygınlığını, \%3'üne göre ise marka ürünün çeşitliliğini ifade ettiğini belirtmişlerdir. Marka tercihi olan kat1lımciların \%34.9'unun daima ve \%57.7'sinin ara sira olmak üzere içme sütündeki marka tercihini başkalarına önerdiği ve \%7'sinin ise asla önermediğ tespit edilmiştir. Tüketicilere içme sütünde tercih ettikleri markanın ambalaj materyali tercihlerinin ne olması gerektiğinin tespitini amaçlayan soru yöneltilmiștir. İçme sütünde marka tercihi olanların \%50.2'sinin cam ambalaj1, \%45'inin karton ambalaj1 ve \%2.3'ünün ise plastik ambalaj1 tercih ettikleri tespit edilmiştir. Sadece katılımcıların \%2.3'ünün fikir beyan etmedikleri belirlenmiştir.

Araştırma kapsamında ayrıca tüketicilere yönlendirilen içme sütü tüketiminde marka tercihine ilişkin faktörler karşısındaki tutumlarını tespite yönelik soruya alınan cevapların analizi yapılmıştır ve sonuçlar Çizelge 3'de tablo halinde sunulmuştur.

Çizelge 3'ye göre, "etkiler" ve "çok etkiler" şeklinde cevap veren katılımcıların bu cevapları bir arada değerlendirildiğinde "güvenilirlik (sağlık-kalite)" \%96.3 oranla ilk sirada tercih edilen faktör olmuştur. Bunu "tat ve lezzet" $(\% 92.6$ oranla) ve "tüketiciye verilen önem/memnuniyet" (\%92.1 oranla) faktörleri takip etmiştir. Aynı çizelgede sadece "çok etkiler" cevap seçeneğine bakıldığında ise katılımcıların içme sütünde marka tercihinde; $\% 42.3$ oranla "güvenilirlik (sağlık/kalite); \%41.4 oranla $(\mathrm{n}=89)$ "tat ve lezzet"; \%35.8 oranla $(\mathrm{n}=77)$ "kalite düzeyi/fiyat istikrarı"; \%34.4 oranla $(\mathrm{n}=74)$ "besinsel içerik ve kıvam"; \%33 oranla $(n=71)$ "tüketiciye verdiği önem/memnuniyet" ilk beș sırada yer almıştır.

\section{Tüketicilerin İçme Sütünde Marka Tercihini Değiştirmede Etkili Olan Faktörlerin Belirlenmesi}

İçme sütü tüketiminde marka tercihi olan katılımcilardan, tercih ettikleri markayı değiștirmelerinde öne çıkan faktörleri etkilenme derecelerine göre sınıflandırılmaları istenmiş ve elde edilen veriler Çizelge 4'te gösterilmiştir.

Çizelge 4'e göre, etkiler ve çok etkiler cevap seçeneklerine göre yapılan analizde; tüketicilerce marka değiştirmede \%93.5 oranla $(\mathrm{n}=201)$ en etkili faktör "kalitenin düşmesi" olmuştur. Ayrıca, içme sütünde kullanılmakta olunan markayı değiştirmede etkili olabilecek faktörler arasında markanın "ayıplı ürün üretenler arasında sayılması" katılımciların \%76.2'sinin $(n=164)$ tercihi ile ikinci sirada, "ürüne erişimde zorluk" faktörü de bir önceki 


\section{İçme Sütü Tüketiminde Marka Seçiciliğinde Etkili Faktörlerin Analizi: İzmir İli Örneği}

faktör gibi katılımcıların \%76.2'sinin $(\mathrm{n}=164)$ tercihi ile ancak çok etkiler seçeneği dikkate alındığında üçüncü sırada yer almıștır. Marka tercihini değiştirmede etkili olabilecek faktörler arasında "üretici firmanın vergi kaçıranlar arasında sayılması" ise katılımciların \%70.3'ünün ( $\mathrm{n}=151)$ tercihi ile dördüncü sırada yer alması önemli bulunmuştur. Firmanın işçi çıkarması katılımcıların \%58.6'sının (n=126) tercihi ile içme sütünde mevcut markanın değiştirilmesinde etkileyici faktörler arasında tercih edilmesi dikkat çekicidir. Ürünün fiyatının yükselmesi faktörü de $\% 51.7$ oranla $(\mathrm{n}=111)$ önemsenen faktörlerden olmuş, ancak anket çalışması sırasında yüz yüze yapılan görüşmelerde, tüketicilerin tercih ettikleri markayı sadece fiyatı yükseldi diye değiştirme eğiliminde olmadıkları gözlemlenmiştir.

Çizelge 3. İçme sütünde marka tercihini etkileyen faktörler

\begin{tabular}{|c|c|c|c|c|c|c|c|c|c|c|}
\hline \multirow[t]{2}{*}{$\begin{array}{l}\text { Süt ve süt ürünlerinde marka } \\
\text { tercihini etkileyen faktörler }\end{array}$} & \multicolumn{2}{|c|}{ Etkilemez } & \multicolumn{2}{|c|}{ Az etkiler } & \multicolumn{2}{|c|}{$\begin{array}{l}\text { Ne etkiler } \mathrm{Ne} \\
\text { etkilemez }\end{array}$} & \multicolumn{2}{|c|}{ Etkiler } & \multicolumn{2}{|c|}{ Çok etkiler } \\
\hline & $\mathrm{n}$ & $\%$ & $\mathrm{n}$ & $\%$ & $\mathrm{n}$ & $\%$ & $\mathrm{n}$ & $\%$ & $\mathrm{n}$ & $\%$ \\
\hline Güvenilirlik (sağllk-kalite) & 2 & 0.9 & 4 & 1.9 & 2 & 0.9 & 116 & 54.0 & 91 & 42.3 \\
\hline $\begin{array}{l}\text { Tüketiciye verdiği önem } \\
\text { /Memnuniyet }\end{array}$ & 8 & 3.7 & 3 & 1.4 & 6 & 2.8 & 127 & 59.1 & 71 & 33.0 \\
\hline Reklam & 52 & 24.2 & 30 & 14.0 & 59 & 27.4 & 62 & 28.8 & 12 & 5.6 \\
\hline Ürünün ambalaj şekli ve dizaynı & 41 & 19.1 & 35 & 16.3 & 39 & 18.1 & 77 & 35.8 & 23 & 10.7 \\
\hline Ambalaj materyali & 24 & 11.2 & 14 & 6.5 & 23 & 10.7 & 106 & 49.3 & 48 & 22.3 \\
\hline Ürün çeşitliliği & 30 & 14.0 & 27 & 12.6 & 59 & 27.4 & 77 & 35.8 & 22 & 10.2 \\
\hline Tat ve lezzet & 8 & 3.7 & 3 & 1.4 & 5 & 2.3 & 110 & 51.2 & 89 & 41.4 \\
\hline Erişim kolaylığg/Bulunabilirlik & 9 & 4.2 & 9 & 4.2 & 17 & 7.9 & 125 & 58.1 & 55 & 25.6 \\
\hline Markanın tanınmışlığı, prestiji & 11 & 5.1 & 13 & 6.0 & 30 & 14.0 & 115 & 53.5 & 46 & 21.4 \\
\hline Fiyat1 & 38 & 17.7 & 26 & 12.1 & 41 & 19.1 & 85 & 39.5 & 25 & 11.6 \\
\hline Kalite düzeyi-fiyat istikrarı & 4 & 1.9 & 2 & 0.9 & 13 & 6.0 & 119 & 55.3 & 77 & 35.8 \\
\hline Raf konumu & 63 & 29.3 & 29 & 13.5 & 46 & 21.4 & 61 & 28.4 & 16 & 7.4 \\
\hline Besinsel içeriği ve kıvamı & 7 & 3.3 & 9 & 4.2 & 9 & 4.2 & 116 & 54.0 & 74 & 34.4 \\
\hline Etiketleme & 39 & 18.1 & 26 & 12.1 & 64 & 29.8 & 67 & 31.2 & 19 & 8.8 \\
\hline Promosyon-fiyat indirimleri & 29 & 13.5 & 23 & 10.7 & 57 & 26.5 & 84 & 39.1 & 22 & 10.2 \\
\hline Kişisel deneyimler & 8 & 3.7 & 9 & 4.2 & 21 & 9.8 & 109 & 50.7 & 68 & 31.6 \\
\hline Eşin dostun tavsiyesi & 34 & 15.8 & 29 & 13.5 & 52 & 24.2 & 87 & 40.5 & 13 & 6.0 \\
\hline
\end{tabular}

Çizelge 4. İçme sütünde marka tercihini değiştirmede etkili faktörler

\begin{tabular}{|l|c|c|c|c|c|c|c|c|c|c|}
\hline \multirow{2}{*}{$\begin{array}{c}\text { İçme sütünde marka } \\
\text { tercihinizi değiştirmenizde } \\
\text { etkili faktörler }\end{array}$} & \multicolumn{2}{|c|}{ Etkilemez } & \multicolumn{2}{|c|}{ Az etkiler } & \multicolumn{2}{c|}{$\begin{array}{c}\text { Ne etkiler Ne } \\
\text { Etkilemez }\end{array}$} & \multicolumn{2}{|c|}{ Etkiler } & \multicolumn{2}{c|}{ Çok etkiler } \\
\cline { 2 - 12 } & $\mathrm{n}$ & $\%$ & $\mathrm{n}$ & $\%$ & $\mathrm{n}$ & $\%$ & $\mathrm{n}$ & $\%$ & $\mathrm{n}$ & $\%$ \\
\hline $\begin{array}{l}\text { Ayıplı ürün üretenler } \\
\text { arasında sayılmas1 }\end{array}$ & 26 & 12.1 & 10 & 4.7 & 15 & 7.0 & 92 & 42.8 & 72 & 33.4 \\
\hline Kalitenin düşmesi & 4 & 1.9 & 6 & 2.8 & 4 & 1.9 & 112 & 52.1 & 89 & 41.4 \\
\hline Ürüne erişimde zorluk & 15 & 7.0 & 10 & 4.7 & 26 & 12.1 & 122 & 56.7 & 42 & 19.5 \\
\hline Yeni ürün çıkaramamak & 57 & 26.5 & 31 & 14.4 & 67 & 31.2 & 47 & 21.9 & 13 & 6.0 \\
\hline Başka markaların etkisi & 40 & 18.6 & 31 & 14.4 & 48 & 22.3 & 79 & 36.7 & 17 & 7.9 \\
\hline Fiyatının yükselmesi & 35 & 16.3 & 37 & 17.2 & 32 & 14.9 & 90 & 41.9 & 21 & 9.8 \\
\hline $\begin{array}{l}\text { Vergi kaçıranlar arasında } \\
\text { sayılması }\end{array}$ & 16 & 7.4 & 16 & 7.4 & 32 & 14.9 & 87 & 40.5 & 64 & 29.8 \\
\hline İşçi çıkarması & 29 & 13.5 & 18 & 8.4 & 42 & 19.5 & 75 & 34.9 & 51 & 23.7 \\
\hline
\end{tabular}

\section{Tartışma}

Mevcut durum itibariyle marka değerini oluşturmak ve uygun biçimde yönetmek her büyüklükteki şirket, her tür sektör ve her tip pazar için bir öncelik haline gelmiştir. Marka, müșterilerin gerçekten istediği yararları karşıladığında gelişir ve ön plana çıkar (Keller,
2013). Örneğin, g1da ürünleri satın almada markanın rolünün sorgulandığı bir araştırmada, kat1lımcıların \%72.4'ünün markanın etkili olduğu görüşüne katıldığı，\%19.6'sının etkili olmadığ1 görüşünü savunduğu, \%8'inin ise fikir beyan etmediği bildirilmiștir (Dilber ve Dilber, 2013). Benzeri bir çalışmada, tüketicilerin 


\section{İçme Sütü Tüketiminde Marka Seçiciliğinde Etkili Faktörlerin Analizi: İzmir İli Örneği}

paketli süt satın alma kararını etkileyen faktörler araștırılmıș ve sütün markasının en önemli faktör olduğu bulunmuştur (Topçu, 2006). Bu bağlamda, bu araştırmada tüketicilerin marka algılarını, marka tercihlerini ve değiştirmelerini etkileyen faktörlerin belirlenmesi amaçlanmıştır.

Süt ve süt ürünlerinde marka tercihini konu alan araştırmalar sınırlı olsa da mevcut araştırma sonuçları pek çok açıdan birbirleriyle uyumlu sonuçlar ortaya koymaktadır. Bu araştırmaya katılan içme sütü tüketen 305 kişiden $215^{\prime}$ 'inin marka tercihi olduğu tespit edilmiştir. Benzeri şekilde, içme sütü konusunda 730 öğrenciyi kapsayan bir araştırmada tüketicilerin \%74.5 oranla marka tercihinin olduğu (Çetinkaya, 2010); 495 kişiyi kapsamına alan bir başka araştırmada da \%78 oranla marka tercihinde bulunulduğu (Şeker ve ark., 2012) tespit edilmiştir. Çebi, Özyürek ve Türkyılmaz (2018) Erzincan'da yaşayan 199 kişinin \% 79.7'sinin marka tercihi olduğunu bulmuşlardır. Erzincan'da yaşayan 400 üniversite öğrencisinin katıldığ 1 bir başka çalışmada katılımcıların \%79.2'sinin süt alırken markaya dikkat ettikleri bulunmuştur (Terzioğlu ve Bakırc1, 2019). Bu çalıșmalarla uyumlu sonuç veren ve 485 öğrenciden oluşan denekleri konu alan çalışmada ise marka tercihi \%77.3 olarak bulunmuştur (Erdem, 2004). Yabanc1 Ayhan, İplikçi ve Şimşek (2018) Ankara'da yurtlarda kalan 588 üniversite öğrencilere anket uygulamış ve bu öğrencilerin \%75.9'unun süt tüketiminde markaya dikkat ettiklerini bulmuştur. Sütte tüketici tercihlerini belirlemek amacıyla gerçekleștirilen ve 354 haneyi kapsayan başka bir çalışmada; hane halklarına göre ürüne ait özellikler içerisinden önemli bulunanlar arasında markanın da yer aldığı görülmüştür (Gündüz ve ark., 2013). Süt ve süt ürünleri tüketim alıșkanlıklarını irdeleyen araştırmada; öğrencilerin \%70.3'ünün süt satın alırken, markasina dikkat ettikleri bildirilmektedir (Uzungöz ve Gülşen, 2007). Say Şahin ve Saraç (2020) Burdur ilinde 65 yaş ve üzeri 400 kişi ile yaptıkları çalışmada, katılımcıların \%56'sının süt alımında markayı önemsediklerini bulmuşlardır. Bu çalıșmaların bulgularına karşın, 1000 kişiyi kapsayan bir araştırmada deneklerin \%53'ünün marka tercihinin olmadiğı, \%47'sinin marka tercihlerinin bulunduğu (Şimșek ve ark., 2005); 350 denekle yapılan bir başka araştırmada ise katılımcıların \%66'sının marka tercihinin bulunmadığı (Akbay ve Tiryaki, 2007) görülmüştür. Benzeri şekilde, Sancak ve Başat Dereli (2019) Tatvan Meslek Yüksek Okulu'nda öğrenim gören 273 öğrencinin sadece \%33.7'sinin süt alırken markasına dikkat ettiklerini bulmuşlardır. Para, Ülger ve Kaliber (2018) 240 Erciyes Üniversitesi öğrencisi ile yaptığı ankette katılımcıların $\% 26.8$ 'i içme sütü tüketirken markanın önemli olduğunu ifade etmişlerdir. Karakaya ve Kızıloğlu (2018) Bingöl ili kent merkezinde yaptıkları anket çalışmasında, katılımcıların sadece $\% 21$ 'i süt alımında markanın önemli ifade etmişlerdir.

İçme sütü tüketiminde marka tercihi ile katılımcıların demografik özellikleri arasında ilişkinin incelendiği bu araştırmada, marka tercihi ile katılımciların marka tercihi ile ilgili bir ilişski bulunmuştur. Genç katılımcıların yaşlı katılımcılarla kıyaslandığında daha fazla marka tercihinde bulundukları tespit edilmiştir. Bunun nedeni genç tüketicilerin sokak sütünü daha az tercih etmeleri ile açıklanabilir. Yabancı Ayhan ve diğerleri (2018) Ankara'da yurtlarda kalan 588 üniversite öğrencilerinin uyguladığı anketin sonucuna göre, öğrencilerin \%52.7'si UHT sütü, $\% 45.5$ 'i pastörize sütü ve $\% 1.8$ 'i sokak sütü tükettiklerini bulmuştur. Celal Bayar Üniversitesi 113 mühendislik fakültesi öğrencisiyle yapılan anket sonucunda; katılımcıların yaklașık \%91'i UHT ya da pastörize süt tüketirken, sadece $\% 5.3$ 'ü sokak sütünü tüketmeyi tercih etmişlerdir (Karagözlü ve ark., 2005). Gümüşhane Üniversitesinde öğrenim gören 120 öğrenci ile yürütülen çalıșmada ise katılımcıların \%27.7'si sokak sütünü tercih etmişlerdir (Şahinöz ve Özdemir, 2017). Nitekim daha homojen örnekleme sahip olan çalışmalarda, sokak sütünün tüketimi artmaktadır. Yirmi sekiz ilde yapılan araştırmaya göre deneklerin \%40'1 sokak sütü tüketmeyi tercih etmişlerdir (Güneş ve ark., 2002). 


\section{İçme Sütü Tüketiminde Marka Seçiciliğinde Etkili Faktörlerin Analizi: İzmir İli Örneği}

Bu çalışma kapsamında katılımcıların daha çok cam ve karton ambalajlı süt almayı tercih ettikleri bulunmuștur. Elazı ̆ ili merkez ilçede yapılan bir çalışmada ise tüketicilerin içme sütü satın alırken $\% 58$ oranla karton kutuyu, $\% 21.2$ oranla camı, \%4.6 oranla plastiği ambalaj materyali olarak tercih ettikleri, $\% 16.2$ oranla da bir fikirlerinin olmadığ 1 bildirilmiştir (Şeker ve ark., 2012). Başka bir çalışmada katılımciların \%60.9'u karton kutuyu tercih etmişlerdir (Karakaya ve Akbay, 2014). Dal, Oral ve Korkmaz (2018) online anket yöntemi kullanarak Burdur ilinde yaşayan 452 üniversite öğrencisinden topladığ 1 verilere göre, süt tüketen 390 katılımcıdan \%61.3'ü süt alırken karton ambalaj1 tercih ederken, \%9.7'si cam ambalaj1 tercih etmişlerdir. Para, Ülger ve Kaliber (2018) çalışmalarında, 240 Erciyes Üniversitesi öğrencisinin içme sütü alımında \%55.4'ü karton ambalaj1, \%37.5'i cam ambalaj1 ve \%3.2'si ise plastik ambalaj1 tercih ettiklerini bulmuşlardır. İstanbul ilinde farklı gelir gruplarından 1000 kişiye uygulanan anket sonucuna göre, bu kişilerin \%52'si cam ambalaj1, \%31'i karton kutuyu, \%6'si plastik ambalajı ve \%11'i ise fikir beyan etmemiştir (Şimşek ve ark., 2005).

$\mathrm{Bu}$ araştırmada, tüketicilerin içme sütü marka seçiminde "Güvenilirlik (sağlık-kalite)", "Tüketiciye verdiği önem /Memnuniyet", "Tat ve lezzet", "Kalite düzeyi-fiyat istikrarı" ve "Besinsel içeriği ve kıvamı" en önemli faktörler olarak bulunmuştur. Her ne kadar gida ürünlerinde marka tercihini etkileyen faktörleri konu alsa da bir araştırmada ürünün ambalaj özellikleri birinci sırada yer alırken, tat ve kıvam ikinci etkileyici faktör olarak tespit edilmiştir (Akpınar ve Yurdakul, 2008). Erzincan ilinde yapılan başka bir araştırmada da ailelerin ambalajlı süt tercihinde $\% 27.47$ oranla markaya önem verdikleri ve bunun nedeni olarak \%30.4 oranla güvenilirlik ile hijyenin önde geldiği vurgulanmıştır (Erdal ve Tokgöz, 2011). Diğer bir çalışmada; markalı süt tüketen tüketicilerin $\% 65.84$ oranla markalı sütlerin kaliteli, sağlıklı, temiz ve kontrollü üretildiğine inandıkları için, \%15.54'ünün ise tanınmış markaya sahip olan firmaların adını korumak istedikleri için \%8.07'sinin firmaya güvendikleri, \%6.21'inin ise bir sorun olduğunda muhatap bulabildikleri için, \%4.34'ünün diğer nedenlerden dolayı markalı süte karşı güven duydukları belirlenmiştir (Demircan ve ark., 2011). Demir ve Güneş (2017), Ankara ilinde yaşayan 122 kişiye uyguladığ1 anket sonucunda, bu kişilerin $\% 52$ 'si süt alırken hijyenik olmasına dikkat ettiğini bulmuşlardır. Yapılan başka bir araştırmada paketli süt satın alma kararında en önemli faktörlerden birinin fiyatı olduğu bildirilmektedir (Topçu, 2006). Sancak ve Başat Dereli (2019) Tatvan Meslek Yüksek Okulu'nda öğrenim gören 273 öğrencinin $\%$ 63.74'ünün süt alırken kalite güvencesine dikkat ettiklerini bulmuşlardır. Tüketicilerin marka tercihini etkileyen faktörlerin de incelendiği bir araştırmada; marka tercihinde TV reklamları en etkili faktör olarak bulunmuştur. Radyo/gazete ve dergi reklamları ile promosyonlu satışların ise nispeten daha az etkili olduğu tespit edilmiştir (Erdal ve Tokgöz, 2011). Dal, Oral ve Korkmaz (2018) online anket yöntemi kullanarak Burdur ilinde yaşayan 390 süt tüketen üniversite öğrencisinin siklıkla aldıkları sütte "tat ve lezzet", "marka memnuniyeti ve tanınmışlığı" ve "kalite ve kalitedeki istikrarı" faktörlerini önemsediklerini tespit etmişlerdir. Ordu ilinde 400 lisans öğrencisinin katıldı ̆̆ tüketicilerin yaklaşık \%80'i marka seçiminde garantinin önemli olduğunu belirtmişlerdir.

Bu çalışmada, katılımcıların marka değişimini etkileyen en önemli faktörler "Ayıplı ürün üretenler arasında sayılması", "Kalitenin düşmesi" ve "Ürüne erişimde zorluk" olarak tespit edilmiştir. Benzeri bir çalışmada ise ürün seçimi neye göre değişir sorusuna en çok verilen cevap \%44 oranda kalite olmuş, bunu \%29 oranla alıșkanlıkların ve \%18 oran ile fiyatın takip ettiği bildirilmiștir. Katılımcıların \%63'ü ise reklamların kullandıkları markayı etkilemediğini bildirmişlerdir (Yılmaz ve ark., 2007). Başka bir araştırmada, marka özgünlüğü, marka tercihi ve müşteri tatmini değişkenlerinin marka sadakatini $\% 90$ gibi yüksek bir oranda açıkladığını ortaya çıkarmıştır (Demirel ve Y1ldı, 2015). Yani, tüketiciler marka değiştirirken bu üç faktörün en az 


\section{İçme Sütü Tüketiminde Marka Seçiciliğinde Etkili Faktörlerin Analizi: İzmir İli Örneği}

önemsemektedirler. Öncül, Sekman, Kınıklı ve Artukoğlu (2019) İzmir ilinde 300 katılımcı ile yaptıkları çalışmada tüketicilerin gıda ürünlerinde marka tercihlerini değiştirmelerinde gıdanın güvenilir ve içeriğin doğal olmasının etkili olduğunu bulmuşlardır.

\section{Sonuç ve Öneriler}

$\mathrm{Bu}$ araştırmada, İzmir ilinde ikamet eden 407 kişinin süt tüketiminde marka algılarını, tercihlerini ve değiştirmelerini etkileyen faktörler anket yardımıyla belirlenmiștir. Çalışmaya katılan süt tüketen 305 kişiden 215 'inin marka tercihi olduğu bulunmuştur. $\mathrm{Bu}$ çalışma kapsamında, genç katılımcıların yaşlı katılımcılarla kıyasla daha fazla marka tercihinde bulundukları tespit edilmiştir. $\mathrm{Bu}$ çalışmaya katılan süt tüketicileri daha çok cam ve karton ambalajlı süt almayı tercih ettikleri bulunmuştur. Katılımcıların içme sütü marka seçimini etkileyen en önemli faktörler "Güvenilirlik (sağlık-kalite)", "Tüketiciye verdiği önem /Memnuniyet", "Tat ve lezzet", "Kalite düzeyi-fiyat istikrarı" ve "Besinsel içeriği ve kıvamı" olarak tespit edilmiştir. Marka değişimini etkileyen en önemli faktörler ise "Ayıplı ürün üretenler arasında sayılması", "Kalitenin düşmesi" ve "Ürüne erişimde zorluk" olarak bulunmuştur.

Tüketicilerin süt tüketiminde marka seçimini ve değişimini etkileyen faktörleri inceleyen yeni araştırmalara ihtiyaç duyulmaktadır. Ayrıca, bu ve benzeri araştırmaların ortaya koyduğu sonuçlar her seviyedeki sektör temsilcileri ve özellikle marka sahiplerince önemle analize tabi tutulmalı, insan ve çevre sağlığını ön plana çıkaran çalışmalar teşvik edilmelidir.

\section{Kaynaklar}

Abu, N. H., Deros, B. M., Abd Wahab, D. ve Ab Rahman, M. N. (2011) Practice of CSFs for the pre-development process in new product innovation processes at SMEs: questionnaire development, Advanced Materials Research, 314: 2318-2323.

Akbay, C. ve Tiryaki, G.Y. (2007) Tüketicilerin ambalajlı ve açı süt tüketim alışkanlıklarının karșılaştırmalı olarak incelenmesi: Kahramanmaraş örneği, KSÜ Fen ve Mühendislik Dergisi, 10(1): 89-96.

Akpınar, M.G. ve Yurdakul, O. (2008) Gida ürünlerinde marka tercihini etkileyen faktörler, Akdeniz Üniversitesi Ziraat Fakültesi, 21(1):1-6.

Aldridge, A. ve Levine, K. (2001) Surveying the Social World: Principles and Practice in Survey Research. Buckingham, Philadelphia: Open University Press.

Ambalajlı Süt ve Süt Ürünleri Sanayicileri Derneği (2019) Sütün tarihi, http://www.asuder.org.tr/sut-ve-suturunleri/sut/sutun-tarihi/, Erişim tarihi 02 Ekim 2019.

Azizağaoğlu, A. ve Altunışık R. (2012) Postmodernizm, sembolik tüketim ve marka, Tüketici ve Tüketim Araştırmaları Dergisi, 4(2): 33-50.

Babbie, E. ve Mouton, J. (2009) The Practice of Social Research. Oxford University Press: Cape Town.

Bocock, R. (1997) Tüketim, (Çev. İ. Kutluk), Dost Kitabevi, Ankara.

Bus, A.E.M. ve Worsley, A. (2003) Consumers' health perceptions of three types of milk: A survey in Australia, Appeite, 40(2): 93-100.

Collins, M. (1986) Sampling (Editör: Worcester, R.M. ve Downhom, J., 1986), Consumer Market Research Handbook, Elsevier Science Publishing Company Inc.

Çakır, M., Çakır, F. ve Usta, G. (2010) Üniversite öğrencilerinin tüketim tercihlerini etkileyen faktörlerin belirlenmesi, Organizasyon ve Yönetim Bilimleri Dergisi, 2(2): 87-94.

Çebi, K., Özyürek, S. ve Türkyılmaz, D. (2018). Süt ve süt ürünleri tüketiminde tüketici tercihlerini etkileyen faktörler: Erzincan ili örneği. Yüzüncü Yll Üniversitesi Tarım Bilimleri Dergisi, 28(1), 70-77.

Çetinkaya, A. (2010) Kafkas üniversitesi öğrencilerinin içme sütü ve süt ürünlerini tüketim alışkanlıklarının belirlenmesi, Atatürk Üniversitesi Veteriner Bilimleri Dergisi, 5(2): 73-84. 


\section{İçme Sütü Tüketiminde Marka Seçiciliğinde Etkili Faktörlerin Analizi: İzmir İli Örneği}

Çınar, R. ve Çubukçu, İ. (2009) Tüketim toplumunun şekillenmesi ve tüketici davranıșları-Karș1laștırmalı bir uygulama-, Atatürk Üniversitesi Sosyal Bilimler Enstitüsü Dergisi, 13(1): 277300.

Dal, N. E., Oral, M. ve Korkmaz, İ. (2018). Genç tüketicilerin içme sütü tüketim alışkanlıkları. International Journal of Social Science, 68(1), 521-547.

Demir, Y. ve Güneş, E. (2017). Ankara ili kırsal alanda süt tüketim düzeylerinin belirlenmesi. Toprak Su Dergisi, 6(1), 28-35.

Demircan, V., Örmeci, M.Ç. ve Kızılyar, G. (2011) Isparta ilinde ailelerin ambalajl1 ve açık süt tüketim alışkanlıklarının karşılaştırmalı olarak incelenmesi, Süleyman Demirel Üniversitesi Ziraat Fakültesi Dergisi, 6(2): 39-47.

Demirel Ülker, E., ve Yıldız, E. (2015) Marka özgünlüğünün marka tercihi, müşteri tatmini ve marka sadakati üzerindeki etkileri: bilgisayar markaları üzerine bir araştırma, Marmara Üniversitesi Öneri Dergisi, 11(44): 83-100.

Dilber, F. ve Dilber, A. (2013) Üniversite öğrencilerinin gıda ürünleri tüketiminde medyanın etkisi: Karamanoğlu Mehmet Bey üniversitesi öğrencileri üzerine bir araştırma, e-Gifder, 2(1):64-82.

Durmaz, Y., Bahar Oruç, R. ve Kurtlar, M. (2011) Kişisel faktörlerin tüketici satın alma davranışlarına etkisi üzerine bir araştırma, Akademik Yaklaşımlar Dergisi, 2(1): 113-132.

Erdal, G. ve Tokgöz, K. (2011) Tüketicilerin ambalajlı ve açık süt tüketim tercihlerini etkileyen faktörler: Erzincan ili örneği, KMÜ Sosyal ve Ekonomik Araştırmalar Dergisi, 13(20): 111-115s.

Erdem, Ş. (2004) Marka Değerini Olușturan Faktörlerin Müşteri Odaklı Ölçümlenmesi ve Süt Ürünleri Sektörüne Yönelik Bir Araştırma, Doktora Tezi, Marmara Üniversitesi Sosyal Bilimler Enstitüsü.

Gavcar, E. ve Didin, S. (2007) Tüketicilerin "perakendeci markalı" ürünleri satın alma kararlarını etkileyen faktörler:
Muğla il merkezinde bir araştırma, Z.K.Ü. Sosyal Bilimler Dergisi, 3(6): 2132.

Gurr, M.L. (1992) Milk products: Contribution to nutrition and health, International Journal of Dairy Technology, 45(3): 6167.

Gündüz, O., Kılıç, O., Emir, M. ve Aydın, G. (2013) Süt ve süt ürünleri tüketiminde tüketici tercihlerini etkileyen faktörler: Samsun ili örneği, Gıda Teknolojileri Elektronik Dergisi, 8(1): 36-43.

Güneş E, Albayrak M, Gülçubuk B. (2002) Türkiye'de Gıda Sanayi, Tekirdağ İş Sendikası Eğitim Yayını, İzmir.

Harvey, D. (2006) Postmodernliğin durumu, (Çev. S. Savran), Metis yayınları, 4.bask1, İstanbul.

Kahraman, E. M. (2016) İçme Sütü Tüketim Alışkanlıkları ve Marka Seçiciliğinde Etkili Faktörlerin Analizi: İzmir İli Örneği, Doktora Tezi, Ege Üniversitesi Fen Bilimleri Enstitüsü, Süt Teknolojisi Ana Bilim Dalı.

Kalton, G. (2009) Methods for oversampling rare subpopulations in social surveys, Survey Methodology, 35(2):125-141.

Karadavut, A. (2016) Türkçede Yeni Bir Neoloji Örneği: Fiilleşen Markalar. Selçuk Üniversitesi Türkiyat Araştırmaları Dergisi, 1(39), 245-252.

Karagözlü, N., Karagözlü, C., Karaca, S. ve Selda, E. (2005) Üniversite öğrencilerinde süt ve ürünleri tüketim alışkanlıkları ve beslenme bilinçleri üzerine bir araştırma. Celal Bayar Üniversitesi Fen Bilimleri Dergisi, 1(2), 101-108.

Karakaya, E. ve Akbay, C. (2014) İstanbul ili kentsel alanda tüketicilerin açık ve paket süt tüketim alışkanlıkları, Tarım Ekonomisi Dergisi, 20(1): 17-27.

Karakaya, E. ve Kızıloğlu, S. (2018). Bingöl ili kent merkezinde tüketicilerin süt ve süt ürünleri tüketim alışkanlıkları. Kahramanmaraş Sütçü İmam Üniversitesi Tarlm ve Doğa Dergisi, 21, 12-21.

Keller, L. K. (2013) Marka karnesi, 113-138, Pazarlamayı Yeniden Keşfetmek 


\section{İçme Sütü Tüketiminde Marka Seçiciliğinde Etkili Faktörlerin Analizi: İzmir İli Örneği}

(Çeviren: İ. Gülfidan), Harward Business Review, MESS Yayın No: 656, İstanbul.

Keskin, S. ve Baş, M. (2016) Sosyal medyanın tüketici davranışları üzerine etkisinin belirlenmesi, Iktisadi ve İdari Bilimler Fakültesi Dergisi, 17(3): 51-69.

Kotler, P. (2000) Pazarlama Yönetimi, (Çev. N. Muallimoğlu), Beta Basın Yayım, İstanbul.

Kotler, P. (2003) Marketing Management, International Edition, Prentice Hall, U.S.A.

Lee, C.K. ve Beatty S.E. (2002) Family structure and influence in family decision making, Journal of Consumer Marketing, 19(1):24-41.

Marangoz, M. (2006) Tüketicilerin marka fonksiyonu algılamaları ile satın alma sonrası davranışları arasındaki ilişki, D.E.Ü.I.I.B.F. Dergisi, 21 (2): 107-108.

Massey, L.K. (2001) Dairy food consumption, blood pressure and stroke, Journal of Nutrition, 131(7): 1875-1878.

Metin, M. (2012) Süt Teknolojisi Sütün Bileșimi ve İşlenmesi, Ege Üniversitesi Rektörlük Yayınları, İzmir

Neal, W.D. (1999) Satisfaction is nice but value drives loyalty, Marketing Research, 2(Spring): 21-23.

Niamsiri, N. ve Batt, C.T. (2009) Dairy products, Encyclopedia of Microbiology, (Third Edition), Schaechter, M. (Ed.), Academic Press Oxford, 34-44.

Onurlubaş, E. ve Çakırlar, H. (2016) Tüketicilerin süt ve süt ürünleri tüketimini etkileyen faktörlerin belirlenmesi üzerine bir araştırma, Çankırı Karatekin Üniversitesi Sosyal Bilimler Enstitüsü Dergisi,7(1):217-242.

Ötleş, S. ve Özyurt, V.H. (2016) Endüstri 4.0: gıda sektörü perspektifi, Dünya Glda Dergisi, (2016/5): 89-96.

Öncül, M., Sekman, Y., Kınıklı, F., \& Artukoğlu, M. (2019). Tüketicilerin gida ürünleri satın alma davranışının incelenmesi: İzmir ili örneği. Tarım Ekonomisi Dergisi, 25(2), 207-217.

Öztürk, D., Karakaş, G. ve Bostanc1, Ş. determination of influencing factors on milk and milk products of students' consuming preferences (Unye pattern). Akademik Sosyal Araştırmalar Dergisi, 4(22), 188-198.

Para G., Ülger, İ. ve Kaliber, M. (2018). Erciyes Üniversitesi öğrencilerinin süt tüketim alışkanlıklarının belirlenmesi üzerine bir araştırma. I $\breve{g} d ı r$ Üniversitesi Fen Bilimleri Enstitüsü Dergisi, 8(1), 329-339.

Roy, T.K. ve Acharya, R. (2016) Statistical Survey Design and Evaluating Impact, Cambridge University Press.

Sancak, H. ve Başat Dereli, D. Tatvan Meslek Yüksekokulu öğrencilerinin süt ve süt tüketimi hakkındaki düşünce ve davranışlar1. Harran Üniversitesi Veteriner Fakültesi Dergisi, 8(1), 7-15.

Sashikala, P. (2007) Emotional intelligence and effectiveness of advertising, Journal of Consumer Behaviour, 2(4):48-58.

Say Şahin, D. Ve Saraç, Z. F. (2020) Burdur İlindeki 65 Yaş Üzeri Tüketicilerin Süt ve Süt Ürünleri Tüketim Alışkanlıkları. Bursa Uludağ Üniversitesi Ziraat Fakültesi Dergisi, 34(1), 119-133.

Sekaran, U. (2002) Research methods for business: A skill building approach (4th ed.). New York: John Wiley \& Sons, Inc.

Şahinöz, S. ve Özdemir, M. (2017) Üniversite öğrencilerinin süt ve süt ürünleri tüketim alışkanlıkları ve etkileyen faktörler. Gümüşhane Üniversitesi Sağlık Bilimleri Dergisi, 6(4), 106-112.

Şeker, İ., Şeker, P., Şahin, M., Özen, V.S., Akdeniz, A., Erkmen, O., Kışlalıoğlu, İ., Sargin, G. ve Doğu, G.B. (2012) Elazığ ili merkez ilçede tüketicilerin süt tüketim alışkanlıkları ve bu alışkanlıkları etkileyen faktörlerin belirlenmesi, F. $\ddot{U}$. Sağllk Bilimleri Veteriner Dergisi, 26(3): 131-143.

Şimşek, O., Çetin, C. ve Bilgin, B. (2005) İstanbul ilinde içme sütü tüketim alışkanlıkları ve bu alışkanlıkları etkileyen faktörlerin belirlenmesi üzerine bir araştırma, Tekirdağ Ziraat Fakültesi Dergisi, 2(1): 23-35.

Terin, M., Bilgiç, A., Güler, İ.O. ve Yavuz, F. (2015) Türkiye'de Süt Ürünleri Süt Ürünleri Tüketim Harcamalarına Etki 
Eden Faktörlerin Analizi: Çoklu Heckman Örneklem Seçicilik Sistem Yaklaşımı, Tarım Bilimleri Dergisi, 21: 500-515.

Terzioğlu, M. E. ve Bakırcı, İ. (2019). Lisans öğrencilerinin süt tüketim alışkanlıklarının ve davranışlarının belirlenmesi. GIDA (2019), 44 (1): 163172

Topçu, Y. (2006) Süt Ürünlerinde Marka Rekabeti ve Tüketici Davranışları: Erzurum İli Örneği, Doktora Tezi, Atatürk Üniversitesi Tarım Ekonomisi Ana Bilim Dal1.

TÜİK (2019) Hayvansal üretim istatistikleri, http://www.tuik.gov.tr/PreTablo.do?alt_i $\mathrm{d}=1002$ (Erişim tarihi: 02 Ekim 2019)

Ulusal Süt Konseyi (2014) Dünya ve Türkiye'de süt sektör istatistikleri 2013, Ulusal Süt Konseyi, Ankara.

Ulusal Süt Konseyi (2019) 2018 Süt raporu: Dünya ve Türkiye'de süt sektör istatistikleri,

https://ulusalsutkonseyi.org.tr/wpcontent/uploads/Sut Raporu_2018_Web Kapakli.pdf, Erişim tarihi: 02 Mart 2020.

Uysal, H. (2012) Ambalajlı sütler hakkında basında yer alan iddialar, Süt Dünyası Dergisi, 7(37): 42-43.

Uzunöz, M. ve Gülşen, M. (2007) Üniversite öğrencilerinin süt ve süt ürünleri tüketim alışkanlıklarının belirlenmesi, Gıda Teknolojileri Elektronik Dergisi, 2 (3): 15-21.

Valentino, N. A. (1999) Crime news and the priming of racial attitudes during evaluations of the president, Public Opinion Quarterly, 293-320.

Yabanc1 Ayhan, N., İplikçi, G. ve Şimşek, I. (2018). Üniversite öğrencilerinin süt ve süt ürünleri tüketimi üzerine bir araştırma. Akademik Sosyal Araştırmalar Dergisi, 6, 370-380.

Yarayan, A. (2015) Almanya'da Türkçe markalara ilişkin yargı kararları, 309330, Türk-Alman Hukukunda Güncel Gelişmeler ve Şirketler Topluluğu Hukuku Uluslararası Sempozyumu, Şenocak, K (Der.), İstanbul.
Y1lmaz, E., Y1lmaz, İ. ve Uran, H. (2007) G1da maddeleri tüketiminde medyanın rolü: Tekirdağ ili örneği, Gıda Teknolojileri Elektronik Dergisi, 2(3): 9-14. 